\title{
KOPI DAPAT MENURUNKAN AKTIVITAS ALT DAN AST SERUM DARAH TIKUS WISTAR ALKOHOLIK
}

\section{COFFEE DECREASED THE ACTIVITY OF ALT AND AST BLOOD SERUM OF ALCOHOLIC WISTAR RATS}

\author{
I Made Sara Wijana ${ }^{1 *}$, Gede Suranjaya ${ }^{2}$, Iriani Setyawati ${ }^{3}$ \\ ${ }^{1}$ Mahasiswa Program S3 Ilmu Kedokteran, Fakultas Kedokteran Universitas Udayana \\ ${ }^{2}$ Laboratorium Statistik, Fakultas Peternakan Universitas Udayana \\ ${ }^{3}$ Laboratorium Struktur dan Perkembangan Hewan, Program Studi Biologi \\ Fakultas MIPA Universitas Udayana \\ *Email: sarawijana1703@gmail.com
}

\section{INTISARI}

Etanol dapat merusak organ hati yang ditandai peningkatan aktivitas alanin amino transaminase (ALT) dan aspartat amino transaminase (AST) serum tikus alkoholik. Kopi yang kaya antioksidan diduga berfungsi sebagai hepatoprotektor. Penelitian ini bertujuan untuk mengetahui apakah kopi dapat menurunkan kadar ALT dan AST serum tikus alkoholik. Tikus putih jantan galur wistar digunakan sebanyak 32 ekor dengan berat $200 \pm 20 \mathrm{~g}$ yang dibagi menjadi 4 kelompok perlakuan, yaitu P0 (kontrol negatif hanya diberi $1 \mathrm{~mL}$ etanol 30\%/200g berat badan (bb)/hari), P1 (1 mL etanol 30\% /200g bb/hari + kopi 0,1g /200g bb dalam 3,5 mL air/ 200g bb/hari), P2 (1 mL etanol 30\% /200g bb/hari + kopi 0,15g /200g bb dalam 3,5 mL air/ 200g bb/hari), dan P3 (1 mL etanol $30 \% / 200 \mathrm{~g} \mathrm{bb} / \mathrm{hari}+$ kopi 0,2g /200g bb dalam 3,5 mL air/200g bb/hari). Pengukuran ALT dan AST dengan metode spektrofotometri. Analisis data dengan ANOVA dilanjutkan uji LSD dan korelasi. Hasil penelitian menunjukkan kopi dapat menurunkan $(\mathrm{P}<0.01)$ aktivitas ALT dan AST darah serum tikus. Aktivitas ALT dan AST berbeda sangat nyata $(\mathrm{P}<0,01)$ antara perlakuan dengan kontrol maupun antar perlakuan. Dosis kopi berkorelasi negatif $(\mathrm{P}<0,01)$ dengan aktivitas ALT dengan koefisien korelasi $(\mathrm{R})-0.978$ dan aktivitas AST dengan koefisien korelasi (R) -0.985. Kadar ALT dan AST paling rendah pada dosis kopi 0,2g/200g bb.

Kata kunci: etanol, ALT, AST, kopi

\section{ABSTRACT}

Ethanol can damage the liver, indicated by an increase of alanin amino transaminase (ALT) activity and aspartat amino transminase (AST) activity in the blood of alcohol-treated rats. Coffee is rich in antioxidants which are hepatoprotector agent. This study aimed to determine the effect of coffee to reduce alanin amino transaminase (ALT) activity and aspartat amino transminase (AST) activity in blood serum of alcohol-treated rats. The study used 32 male wistar albino rats $(200 \pm 20 \mathrm{~g}$ weight $)$ which were divided into four treatment groups i.e. P0 (negative control which were treated with $1 \mathrm{~mL}$ of $30 \%$ ethanol/200g body weight (bw)/day), P1 (1 mL of 30\% ethanol/200 g bw/day + coffee $0,1 \mathrm{~g} / 200 \mathrm{~g}$ bw in $3,5 \mathrm{~mL}$ of water/200 g bw/day), P2 $(1 \mathrm{~mL}$ of $30 \%$ ethanol $/ 200 \mathrm{~g}$ bw + coffee $0,15 \mathrm{~g} / 200 \mathrm{~g}$ bw in $3,5 \mathrm{~mL}$ of water/200g bw/day), dan P3 (1 mL of 30\% ethanol/200g bw + coffee $0,2 \mathrm{~g} / 200 \mathrm{~g} \mathrm{bw}$ in $3,5 \mathrm{~mL}$ of water/200g bw/day). ALT and AST levels were measured by spectrophotometric method. Data analysis was done by ANOVA followed with LSD test and correlation analysis. The results showed that coffee reduced $(\mathrm{P}<0.01)$ the activities of ALT and AST of rats blood serum. ALT and AST activities were significantly different $(\mathrm{P}<0.01)$ among treatments and with control. Dose of coffee was negatively correlated with ALT activity with correlation coefficient (R) -0.978 and AST with correlation coefficient $(\mathrm{R})-0.985(\mathrm{P}<0,01)$. The lowest of ALT and AST activities were found at dose of coffee $0.2 \mathrm{~g} / 200 \mathrm{~g}$ body weight.

Keywords: ethanol, ALT, AST, coffee

\section{PENDAHULUAN}

Antioksidan alami pada kopi telah diteliti oleh Chu et al. (2008) dengan teknik elektroforesis kapiler dan deteksi amperometrik, dan ditemukan bahwa kopi mengandung katesin $(188,0 \mu \mathrm{g} / \mathrm{g})$, rutin $(169,6 \mu \mathrm{g} / \mathrm{g})$, asam firulat $(57,7 \mu \mathrm{g} / \mathrm{g})$, asam klorogenat $(8.638,9 \mu \mathrm{g} / \mathrm{g})$, kafein $(114,8 \mu \mathrm{g} / \mathrm{g})$, dan asam galat $(64,2 \mu \mathrm{g} / \mathrm{g})$. Semuanya tergolong senyawa polifenol. Antioksidan pada kopi diduga memiliki khasiat sebagai hepatoprotektor. Kopi juga diketahui mengandung minyak yang disebut kahweol dan kafestol (Morii et al., 2009 dan Vecchia, 2005). Kahweol dan kafestol merupakan dua senyawa yang tergolong senyawa diterpen yang bersifat sebagai antioksidan dan sebagai antikarsinogenik (Nkonjock, 2009). Kopi juga diketahui mengandung tokoferol (Alves et al., 2010).

Enzim alanin amino transaminase (ALT) dan enzim aspartat amino transaminase (AST) adalah enzim yang terlibat dalam interkonversi antara asam amino dan asam keto. Kedua enzim tersebut terdapat di dalam mitokondria yang dibutuhkan dalam metabolisme nitrogen dan karbohidrat. Telah ditemukan bahwa ALT merupakan marka yang lebih baik untuk mendeteksi fungsi hati, karena ALT adalah enzim yang disintesis di dalam sel hati (hepatosit), maka enzim ini berfungsi lebih spesifik untuk penyakit hati dibandingkan enzim lainnya (Baynes dan Dominiczak, 2005). Peningkatan aktivitas ALT serum biasanya terjadi bila ada kerusakan membran sel hepatosit. Setiap jenis peradangan hati dapat menyebabkan peningkatan kadar ALT. Peradangan pada hati dapat disebabkan oleh virus hepatitis, beberapa obat, konsumsi alkohol, dan penyakit pada saluran cairan empedu.

Oksidasi enzimatik etanol pertama terjadi di dalam hati, kemudian di dalam ginjal yang melibatkan tiga jenis enzim. Proses pertama di dalam hati adalah $90-98 \%$ etanol dimetabolisme atau dioksidasi menjadi asetaldehid oleh alkohol dehidrogenase (ADH). Proses kedua asetaldehid dioksidasi lebih lanjut menjadi asam asetat oleh enzim asetaldehid dehidrogenase (ALDH) menjadi asetat. Kedua reaksi tersebut menggunakan kofaktor atau koenzim Nikotinamid Dinukleotida (NAD). Kofaktor NAD mempunyai bentuk molekul ion $\mathrm{NAD}^{+}$. Setelah terjadi oksidasi, NAD selanjutnya tereduksi menjadi NADH (Arthur et al., 2009). Beberapa senyawa yang terbentuk akibat metabolisme alkohol dalam tubuh adalah asetealdehid, FAEE (Fatty Acid Ethyl Ester), ester kolesteril atau Cholesteryl Esters (CE), dan malondialdehid (MDA). Hasil metabolit tersebut dapat mengakibatkan stres oksidatif (Arthur et al., 2009). Asetaldehid dan radikal bebas dapat merusak sel-sel hati (Corwin, 2001)

Penelitian ini bertujuan untuk mengetahui apakah kopi dapat meningkatkan kadar alanin amino transaminase (ALT) dan aspartat amino transaminase (AST) serum darah tikus alkoholik. 


\section{MATERI DAN METODE}

Penelitian dilakukan di Laboratorium Pangan dan Gizi Universitas Gajah Mada Yogyakarta pada bulan Mei-Juli 2017. Penelitian menggunakan rancangan Post Test Only Control Group Design dengan Rancangan Acak Lengkap (RAL). Obyek penelitian adalah tikus putih jantan galur Wistar dengan berat $200 \pm 20 \mathrm{~g}$. Variabel bebas adalah dosis suspensi kopi $0,1 \mathrm{~g} / 200 \mathrm{~g}$ berat badan $(\mathrm{bb}) ; 0,15 \mathrm{~g} / 200 \mathrm{~g}$ bb, dan $0,2 \mathrm{~g} / 200 \mathrm{~g}$ bb.

Kopi yang digunakan jenis Arabica yang dibeli dari pengolahan biji kopi di Dusun Lankan Desa Landis Kecamatan Bangli, Kabupaten Bangli, Provinsi Bali. Suspensi kopi dibuat dengan cara serbuk kopi diseduh dengan air panas tanpa tambahan bahan lainnya. Suspensi kopi yang diberikan didasarkan pada batas maksimal konsumsi kafein pada manusia yaitu $895 \mathrm{mg} / 60 \mathrm{~kg} \mathrm{bb} / \mathrm{hari}$ (Choi and Curhan, 2010), dengan kandungan kafein pada kopi diprediksi $149 \mathrm{mg} / 10 \mathrm{~g}$ serbuk kopi, sehingga jumlah kopi yang boleh diseduh dan dikonsumsi sebanyak $60 \mathrm{~g} /$ hari untuk orang yang berat badannya $60 \mathrm{~kg}$. Berdasarkan hal tersebut, batas maksimal kopi yang diberikan per ekor tikus dengan berat $200 \mathrm{~g}$ adalah $0,2 \mathrm{~g}$ /hari. Kemudian dosis tersebut dibuat menurun secara bertingkat yaitu $0,15 \mathrm{~g} / 200 \mathrm{~g} \mathrm{bb} / \mathrm{hari}$ dan $0,10 \mathrm{~g} / 200 \mathrm{~g} \mathrm{bb} / \mathrm{hari}$. Masing-masing dosis diseduh dalam air panas sebanyak $3,5 \mathrm{~mL}$.

Alkohol yang dimaksud adalah etanol. Etanol adalah senyawa kimia etil alkohol dengan rumus kimia $\mathrm{CH}_{3} \mathrm{CH}_{2} \mathrm{OH}$. Etanol digunakan dengan konsentrasi $30 \%$ yang diberikan sebanyak $1 \mathrm{~mL}$ per oral setiap hari selama 56 hari (8 minggu).

Empat puluh tikus jantan galur Wistar umur 8-9 minggu diadaptasikan selama satu minggu, kemudian diambil 32 ekor dengan berat $200 \pm 20 \mathrm{~g}$ secara acak kemudian dibagi ke dalam 4 kolompok perlakuan. Setiap individu diletakkan di dalam satu kandang. Kandang dikondisikan seperti alami dengan tetap memperhatikan pencahayaan dan suhu. Pakan yang diberikan pada semua tikus selama adaptasi dan masa penelitian adalah sama yaitu pakan standar yang diberikan secara ad libitum. Pemberian pakan dilakukan setiap hari pada pukul 08.00-09.00 WIB dan penimbangan berat badan dilakukan setiap 2 hari sekali. Pemberian kopi dengan dosis bertingkat dilakukan pada sekitar pukul 10.00 WIB untuk kelompok perlakuan. Pemberian alkohol 30\% sebanyak $1 \mathrm{~mL}$ diberikan kepada semua individu tikus setiap hari pada sekitar pukul $12.00 \mathrm{WIB}$. Empat kelompok tikus adalah sebagai berikut: P0 (kontrol) hanya diberikan $1 \mathrm{~mL}$ etanol 30\%/200g bb/hari, P1 diberikan 1 $\mathrm{mL}$ etanol 30\%/200g bb + kopi 0,1g/200g bb dalam 3,5 mL air/200g BB/hari, P2 diberikan $1 \mathrm{~mL}$ etanol 30\%/200g bb + kopi $0,15 \mathrm{~g} / 200 \mathrm{~g}$ bb dalam $3,5 \mathrm{~mL}$ air/200g bb/hari, dan $\mathbf{P 3}$ diberikan $1 \mathrm{~mL}$ etanol $30 \% / 200 \mathrm{~g}$ bb + kopi $0,2 \mathrm{~g} / 200 \mathrm{~g}$ bb dalam 3,5 mL air/200g bb/hari.

Pengambilan darah dilakukan sehari sebelum perlakuan dilaksanakan (pre test) dan pada hari ke 57 (post test). Pengambilan darah pre test dilakukan pada flexus retroorbitalis sebanyak $3 \mathrm{~mL}$. Pengambilan darah pada post test dilakukan dengan dianestesi terlebih dahulu menggunakan kloroform. Darah diambil secara intrakardial menggunakan spuit sebanyak $3 \mathrm{~mL}$. Pengukuran kadar ALT dan AST dilakukan dengan metode spektrofotometri dengan panjang gelombang $334 \mathrm{~nm}$ pada suhu $25-37^{\circ} \mathrm{C}$.

Normalitas data dianalisis dengan Uji KolmogorovSmirnov. Bila data terdistribusi normal maka dilakukan uji Anova One Way dan uji lanjutan Duncan dan bila distribusi data tidak normal maka dilakukan uji Kruskal Wallis dan uji lanjutan Mann Whitney.

\section{HASIL DAN PEMBAHASAN}

Untuk melihat efek etanol, dilakukan pengukuran aktivitas ALT dan AST sebelum percobaan dilaksanakan (pre test) sebagai pembanding dengan kontrol positif (P0), hasilnya ditampilkan pada Tabel 1.

\begin{tabular}{|c|c|c|}
\hline Waktu & $\begin{array}{c}\text { Kadar ALT } \\
(\mathrm{U} / \mathrm{L})\end{array}$ & $\begin{array}{c}\text { Kadar AST } \\
\text { (U/L) }\end{array}$ \\
\hline Pre test & $18,08 \pm 0,34$ & $36,90 \pm 0,73$ \\
\hline Post test $(\mathrm{P} 0)$ & $38,11 \pm 1,19$ & $77,19 \pm 1,96$ \\
\hline
\end{tabular}

Tabel 1 menunjukkan bahwa aktivitas ALT dan AST sebelum perlakuan dilakukan dalam kisaran normal, ini sesuai pernyataan Pilichos et al. (2004), bahwa aktivitas ALT dan AST pada serum darah tikus putih normal berkisar antara 19,3$68,9 \mathrm{U} / \mathrm{L}$ dan 29,8-77,0 U/L. Etanol 30\% yang diberikan meningkatkan kadar ALT dan AST dua kali lipat. Hasil ini sesuai dengan penelitian Sutirta-Yasa dkk (2011), aktivitas ALT dan AST serum darah mencit yang diberi alkohol meningkat 2 kali lipat dibandingkan dengan mencit normal. Sesuai Surat Keputusan Menteri Kesehatan RI No.1516/A/SK/V/81 dan Peraturan Menteri Kesehatan RI No. 86 Menkes/Per/IV/77. Alkohol 30\% tergolong alkohol golongan C (whisky, brandy, arak, vodka 20-55\%). Alkohol $30 \%$ yang diberikan setiap hari selama 8 minggu telah memberi efek kronis terhadap fungsi hati (Singh et al., 2010). Rasio AST/ALT pada P0>2 ini merupakan petanda hepatitis alkoholik (Mendenhall, 1981; William dan Hoofnagel, 1988). Meningkatnya aktivitas ALT dan AST dalam serum darah karena terjadi kematian sel (apotosis) dan kerusakan jaringan yang menyebabkan enzim ALT dan AST keluar dari sel hepatosit dan masuk ke dalam sistem peredaran darah. Kedua enzim tersebut merupakan marka untuk mendeteksi fungsi hati.

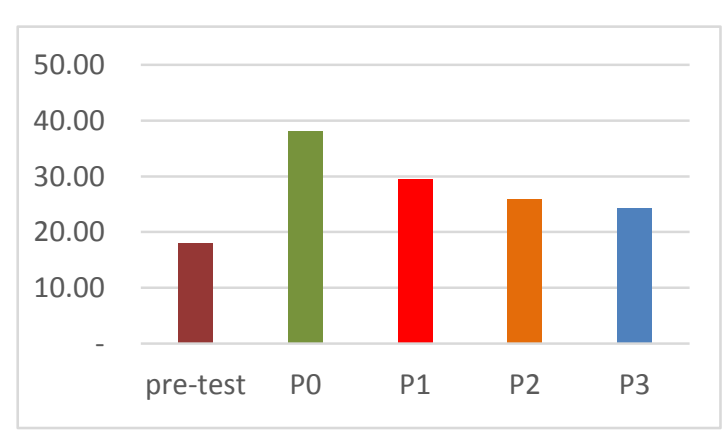

Gambar 1 Grafik aktivitas ALT 


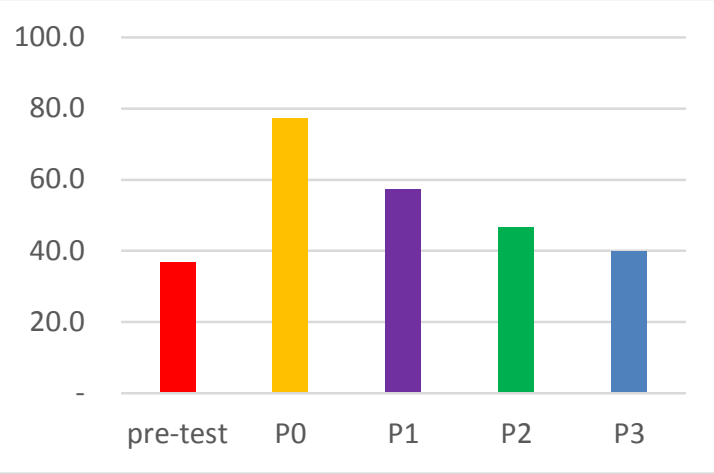

Gambar 2. Grafik Aktivitas AST

Uji Kolmogorof-Smirnov, menunjukkan bahwa data berdistribusi tidak normal dengan $\mathrm{P}<0,05$. Hasil uji Kruskal
Wallis dan uji lanjutan Mann Whitney aktivitas ALT dan AST disajikan pada Tabel 2 dan 3.

Tabel 2. Aktivitas ALT

\begin{tabular}{ccccc}
\hline \multirow{2}{*}{ Perlakuan } & \multicolumn{5}{c}{ Aktivitas ALT } \\
& Mean Rank & Chi Square & P (Probabilitas) & $($ Mean $\pm S D, \mathrm{U} / \mathrm{L})$ \\
\hline P0 & $28,50^{\mathrm{a}}$ & & & $38,11 \pm 1,19$ \\
P1 & $20,50^{\mathrm{b}}$ & 29,219 & 0,001 & $29,55 \pm 0,61$ \\
P2 & $12,50^{\mathrm{c}}$ & & & $26,03 \pm 0,57$ \\
P3 & $4,50^{\mathrm{d}}$ & & & $24,34 \pm 0,55$ \\
\hline
\end{tabular}

Keterangan: Mean Rank dengan huruf superscript yang berbeda menunjukkan perbedaan yang sangat signifikan $(\mathrm{P}<0,01)$.

\begin{tabular}{ccccc}
\multicolumn{5}{c}{ Tabel 3. Aktivitas AST } \\
\hline \multirow{2}{*}{ Perlakuan } & \multicolumn{5}{c}{ Aktivitas AST } \\
& Mean Rank & Chi Square & P (Probabilitas) & $($ Mean $\pm S D$, U/L) \\
\hline P0 & $28,50^{\mathrm{a}}$ & & & $77,19 \pm 1,96$ \\
P1 & $20,44^{\mathrm{b}}$ & \multirow{2}{*}{29,054} & 0,001 & $57,23 \pm 3,31$ \\
P2 & $12,56^{\mathrm{c}}$ & & & $46,61 \pm 2,43$ \\
P3 & $4,50^{\mathrm{d}}$ & & & $39,93 \pm 0,72$
\end{tabular}

Keterangan: Mean Rank dengan huruf superscript yang berbeda menunjukkan perbedaan yang sangat signifikan $(\mathrm{P}<0,01)$.

Kopi berpengaruh terhadap turunnya aktivitas ALT dan AST dalam serum darah tikus $(\mathrm{P}<0,01)$. Tabel 2 dan 3 serta Gambar 1 dan 2 menunjukan bahwa peningkatan dosis kopi memberi efek yang lebih besar terhadap turunnya aktivitas ALT dan AST serum darah tikus. Hasil ini sesuai dengan penelitian Xiongwen et al. (2010), bahwa peningkatan dosis kafein menurunkan aktivitas ALT dan AST. Uji Mann Whitney menunjukkan masing-masing dosis kopi menimbulkan efek yang sangat nyata $(\mathrm{P}<0,01)$ baik terhadap kontrol maupun antar dosis. Dosis kopi berkorelasi negatif dengan kadar ALT $(\mathrm{R}=-0,978)$ dan AST $(\mathrm{R}=-0,985)$ dengan $\mathrm{P}<0,01$. Penurunan aktivitas ALT dan AST paling tinggi terjadi pada perlakuan dosis kopi 0,2 g/200g bb. Aktivitas ALT dan AST berhubungan dengan apoptosis dan kerusakan jaringan hati. Dengan menurunkan kadar ALT dan AST, berarti kopi dapat menurunkan tingkat apotosis dan kerusakan jaringan, dengan demikian kopi dapat mengurangi efek etanol terhadap apoptosis dan kerusakan jaringan organ hati. Hal ini disebabkan karena kopi kaya akan antioksidan. Katesin, salah satu senyawa aktif dalam kopi, dapat meningkatkan kandungan antioksidan endogen SOD (superoksida dismutase), CAT (catalase) dan GPx (glutation peroksidase) pada tikus alkoholik (Barrhan et al., 2011). SOD, CAT dan GPx merupakan antioksidan endogen yang penting sebagai marker terjadinya stres oksidatif dan tingkat kerusakan hati yang kadarnya tergantung pada tingkat kerusakan hati (Cesaratto et al.,2004)

\section{KESIMPULAN}

Dalam penelitian ini, kopi dapat menurunkan aktivitas ALT dan AST serum darah tikus alkoholik dan dosis kopi berkorelasi negatif dengan kadar ALT dan AST. Kadar ALT dan AST paling rendah pada dosis kopi 0,20 g/200g bb.

\section{UCAPAN TERIMA KASIH}

Ucapan terima kasih disampaikan kepada Bapak Julianto sebagai laboran Laboratorium Pangan dan Gizi Universitas Gajah Mada Yogyakarta atas batuannya selama penelitian berlangsung.

\section{KEPUSTAKAAN}

Alves, R.C., S. Casal, M. Beartric, and P.P. Oliveira. 2010. Tocopherol in coffee brews : Influence of coffee species, roast degree and brewing procedure. J. of Food Composition and Analysis 23: 802-808. www.elsevier.com/locate/jfca

Arthur, I., Cederbaum, L. Yongke, and W. Defeng. 2009. Role of oxidative stress in alcohol-induced liver injury. Arch Toxicol. 83:519-548.

Barrhan, S., A. Koul, K. Chopra, and P. Rhisi. 2011. Catechin suppresses an array of signalling molecules and modulates alcohol-induced endotoxin mediated liver injury in a rat model. PLOS ONE 6:1-9.

Baynes, J.W and M.H. Dominiczak. 2005. Medical Biochemistry ${ }^{\text {rd }}$ Ed. Toronto. Elsevier Mosby.

Cesaratto, L., C. Vascotto, S. Calligaris and G. Tell. 2004. The importance of redox state in liver damage. Annal of Hepatology 3(3):86-92. 
Choi, H.K. and G. Curhan. 2010. Coffee consumption and risk of incident gout in women: the nurses' health study, Am. J. Clin. Nutr. 92(4)922-927.

Chu, Q., M. Lin, and X. Yu. 2008. Study on extraction efficiency of natural antioxidant in coffee by capillary electrophoresis with amperometric detection. Eur. Food Res. Technol. 1373-1478

Corwin, J.E. 2001. Buku Saku Patofisiologi. Penerbit Buku Kedokteran EGC. Jakarta.

Mendenhall, C.L. 1981. Alcoholic hepatitis. Clin. Gastroenterol. 10:417-441.

Morii, H., A. Kuboyama, T. Nakashima, K. Kawai, H. Kasai, K. Tamae and T. Hirano. 2009. Effects of instant coffee consumption on oxidative DNA damage, DNA repair, and redox system in mouse liver. Journal of Food Science 74:155-161.

Nkonjock, A. 2009. Coffee consumption and the risk of cancer: an overview. Cancer Letters 277:11-125. www.elsevier.com/locate/canlet
Pilichos, C., D. Perrea, M. Demonakou, A. Preza, and I. Donta. 2004. Management of carbon tetrachloride-induced acute liver injury in rats by syngeneic hepatocyte transplantation in spleen and peritoneal cavity. Word J. Gastroenterol. 10(14):2009-2102.

Sutirta-Yasa, I.W.P., I M. Jawi, I.B. Ngurah, A.A.N. Subawa. 2011. Umbi ubi jalar ungu Bali (Ipomea batatas) di transaminase serum, malondialdehid hepar dan alkohol kronis. Majalah Patologi Klinik Indonesia dan Laboratorium Medik. 17(3):151-154

Vecchia, C.L. 2005. Coffee, lever enzymes, cirrhosis and liver cancer. Journal of Hepatology. 42:444-445. www.elsevier.com/locate/jhep

Williams, A.L. and J.H. Hoofnagle. 1988. Ratio of serum aspartate to alanine amino transferase in chronic hepatitis. Relationship to cirrhosis. Gastroenterology 95: 734-739.

Xiongwen, L.V., Z. Chen, J. Li, L. Zhang, H. Liu, C. Huang, and P. Zhu. 2010. Caffeine protects against alcoholic liver injury by attenuanting inflammatory response and oxidative stress. Inflan. Res. 59:635-645. 